\title{
THE DRAFTING OF HOUSING LEGISLATION
}

\author{
RAlph K. Chase*
}

This article is limited in scope to a discussion of certain problems connected with the drafting of legislation providing for the carrying on of slum clearance and lowcost housing activities by "public bodies," and particularly by public corporate bodies known as "housing authorities." Before considering the detailed provisions of housing authority legislation, however, it is necessary to consider (a) certain prior state legislation relating to slum clearance and low-cost housing in which it may be desirable to integrate the housing authority act and (b) the applicable provisions of the Emergency Relief and Construction Act of 1932 and the National Industrial Recovery Act which gave housing legislation its recent impetus.

\section{Limited Dividend Housing Laws and the Emergency Relief and Construction Act of 1932}

Laws providing for the organization, operation and regulation of limited dividend housing companies were enacted in New York in $1926 .{ }^{1}$ Similar laws were later adopted in twelve other states, principally because of the provisions of the Emergency Relief and Construction Act of 1932, which authorized the Reconstruction Finance Corporation, among other things, to

"make loans to corporations formed wholly for the purpose of providing housing for families of low income, or for reconstruction of slum areas, which are regulated by State or municipal law as to rents, charges, capital structure, rate of return, and areas and methods of operation, to aid in financing projects undertaken by such corporations which are self-liquidating in character;"2

At the time of the adoption of that act (July 2r, I932) only New York had a state housing law providing for the organization of corporations which could qualify under the above-quoted provision. Accordingly, the New York housing law, with more or less local variations in each case, was adopted in twelve other states and many limited dividend housing companies were organized to endeavor to secure

- S.B., r922, Union, LL.B., I927, Harvard. Head of Legal Division of Housing Division of Public Works Administration. Formerly associated with Root, Clark, Buckner and Ballantine, attorneys, of New York City. Member of the New York and Massachusetts Bars.

${ }^{2}$ N. Y. Laws 1926 , c. 823 ; amended: N. Y. Laws 1927 , c. 35; N. Y. Laws 1928, c. 722; N. Y. Laws 1930, c. 872; N. Y. Laws 1931, c. 557-558; N. Y. Laws 1932, c. 507; N. Y. Laws 1933, c. 802.

${ }^{2}$ Act of July 21, 1932, c. $520, \$ 20$ (a) (4), 47 STAT. 7II, 15 U. S. C. A. (Supp.) $\$ 605 b$ (2) (r). 
federal assistance in the financing of slum clearance and low-cost housing projects. The essentials of all such limited dividend housing laws are

I. Limitation of return to the amount contributed, plus interest or dividends at a rate not to exceed that named in the law, usually $6 \%$;

2. Payment of all excess to the state; and

3. Supervision and control by a state housing board created for that purpose.

\section{The National Industrial Recovery Act}

The next step in the making available of federal funds for slum clearance and low-cost housing projects was the passage of the National Industrial Recovery Act ${ }^{3}$ which was approved on June 16 , I933. Section 202 reads in part as follows:

The Administrator, under the direction of the President, shall prepare a comprehensive program of public works, which shall include among other things the following: . . (d) construction, reconstruction, alteration, or repair under public regulation or control of low-cost housing and slum clearance projects;

and Section 203 (a) provides among other things that

With a view to increasing employment quickly (while reasonably securing any loans made by the United States) the President is authorized and empowered, through the Administrator or through such other agencies as he may designate or create, (I) to construct. finance, or aid in the construction or financing of any public works project included in the program prepared pursuant to section 202; (2) upon such terms as the President shall prescribe, to make grants to states, municipalities, or other public bodies for the construction, repair, or improvement of any such project, but no such grant shall be in excess of $3^{\circ}$ per centum of the cost of the labor and naterials employed upon such project;

Unlike the Emergency Relief and Construction Act the National Industrial Recovery Act, it will be noted, does not limit qualified borrowers for slum clearance and low-cost housing projects to limited dividend housing corporations. All that is required is that the construction, reconstruction, alteration or repair of low-cost housing and slum clearance projects be "under public regulation or control." Nevertheless the great bulk of applications continued to come in from limited dividend housing companies and in cases where there was no provision for the formation of such companies the limited dividend set-up was closely approximated, the limitation upon participation being secured by the creation of two classes of stock and the public regulation or control being secured by the loan agreement between the borrower and the United States.

Recently, however, the Federal Emergency Administrator of Public Works, Secretary Ickes, decided to entertain no further applications from private housing companies, and accordingly slum clearance and low-cost housing projects with the aid of Public Works Administration funds (at least for the time being) can be carried on only by (a) federal construction or (b) federal financing of projects to be carried on by public bodies.

${ }^{3}$ Act of June I6, I933, c. 90, 48 Stat. 95, 40 U. S. C. A. (Supp.) c. 8. 
With the probable exception of a very few cities which appear to have power in their charters to engage in housing activities, no state, municipality or other public body was at the time of the adoption of the National Industrial Recovery Act specifically authorized to carry on any low-cost housing or slum clearance projects, and it should be emphasized that limited dividend housing companies, part of the income of which goes to the payment of dividends to private investors, are not public bodies within the meaning of that term as used in the National Industrial Recovery Act.

\section{The General Legislative Problem and Preliminary Determinations}

The immediate problem thus presented to state legislatures is quite simple:the enactment of legislation providing for the carrying on of low-cost housing and slum clearance projects by public bodies, loans to which may be reasonably secured. The possible solutions to this problem are numerous and varied. The lack of uniformity of legislation is explained partly by the breadth of the term "public bodies" as distinguished from the particularity of the description of eligible borrowers set forth in the clause from the Emergency Relief and Construction Act quoted above, partly by the absence of any form of act which would meet the problem and which had been tested in practice and amended by successive legislatures, such as the New York act in the field of limited dividend housing companies, and partly by peculiarities of local conditions and drafting. Thus of the first four acts adopted, the Ohio law* provides for the creation of housing authorities for a territory comprising less than one county but more than two townships; the Maryland law ${ }^{5}$ provides for the establishment of a single state board to receive and administer funds loaned or granted by the federal government; the Michigan law ${ }^{6}$ provides for the creation of city commissions to act in part independently but in part through the city council; and the New Jersey law ${ }^{7}$ provides for the establishment of a state-wide housing authority.

The decision as to what kind of public body should be authorized to engage in housing activities must be answered in the light of state law and local conditions. The state constitution may prohibit the state from engaging in works of "internal improvement." If so, a careful examination of decisions defining the term "internal improvement" and limiting the scope of the constitutional provisions is essential. In a state where the decisions indicate the possibility that such constitutional provisions may prohibit a city from engaging in slum clearance and low-cost housing activities, a careful study should be made to determine whether or not such prohibition might apply to a separately constituted public body such as a housing authority. Michigan is one of the states in which these constitutional questions are particularly acute, especially since, as indicated above, the Michigan housing law, which was recently enacted, provides for the carrying on of housing activities by city commissions rather than by separately constituted housing authorities.

\footnotetext{
'Ohio Laws I933, Ist Spec. Sess., H. B. I9.

Md. Laws r933, c. 32.

-Mich. Pub. Acts 1933, 2nd Extra Sess., No. II, \$4.

'N. J. Laws I933, c. 444 .
} 
In Michigan there is also presented the question of the possible applicability of Article 5, Section 30 of the state constitution which provides:

The legislature shall pass no local or special act in any case where a general act can be made applicable, and whether a general act can be made applicable shall be a judicial question. No local or special act shall take effect until approved by a majority of the electors voting thereon in the district to be affected.

The major amendments to that bill introduced on the floor were the substitution of the governor in place of the mayor as the appointing authority ${ }^{8}$ and the insertion of a phrase limiting the operation of the act to any city or incorporated village "in any county having a population over 500,000 according to the last federal census." The obvious intent was to limit the operation of the act to the City of Detroit, and it is frequently referred to as the Detroit Slum Clearance Act. The effect of the change, however, is to make a distinction between cities not on the basis of their population but on the total population of the county in which they happen to be located. Thus the Wayne County line may separate two cities with precisely similar housing problems, and under the act one of these cities is authorized to engage in slum clearance and low-cost housing activities while the other has no such right. Under the constitutional provision quoted above this may render the entire act invalid.

In Illinois ${ }^{10}$ an interesting problem of legislative drafting arose in connection with the definition of the powers of the state housing board with respect to housing authorities. Because of a peculiar and decidedly involved series of decisions on amendment by reference, some eminent local counsel felt that the inclusion in the housing authority law of provisions expanding the powers of a board created by another act might be unconstitutional and, accordingly, the provisions of the housing authority bill relating to the powers of the state housing board were repeated in another act which amended the state housing law which provided for the formation of limited dividend housing companies and for their regulation by the state housing board created pursuant to that act. The Illinois situation in this respect does not appear to be typical.

In Delaware the question was raised in discussion of the housing authority bill before the legislature as to the effect of Section I of Article 9 of the Delaware Constitution which provides in part that "no corporation shall hereafter be created, amended, renewed or revived by special act but only by or under general law." A review of the decisions, however, led to the conclusion that this provision was not applicable, especially in view of the fact that the Delaware bill, following in general outline the same form as the Illinois Housing Authority Law, set forth a mechanism under which housing authorities might be created in different counties throughout the state and did not of itself create any corporate body.

${ }^{8}$ Mich. Pub. Acts $x 933$, 2nd Extra Sess., No. $11, \$ 4$.

'Ibid., \$3.

${ }^{20}$ Illinois Laws 1933, 3rd Spec. Sess., H. B. 4 and 5. 
Relation of Housing Authority to State Housing Board

After a careful examination of the constitutional and statutory provisions, it is essential to study carefully other legislation dealing with similar subject matter or which might affect the working of the housing authority law. One of the most puzzling questions is that of the relationship between the housing authorities and the state housing board where a state housing board has been created under a housing act providing for the formation and regulation of limited dividend housing companies. Where the state housing board is inactive it may be advisable (particularly in view of the certainty of detailed federal control of projects financed by federal funds) to ignore its existence in the drafting of a housing authority act. Where a state housing board is intelligently active, however, it would seem desirable to make available its accumulated experience, without, however, requiring a duplication of control in the case of a project financed and, therefore, rigorously supervised and controlled by the federal government.

The Illinois Housing Authority Law seems to suggest a reasonable solution to this problem. Housing authorities are subjected to the same control as limited dividend housing companies except with respect to projects financed and supervised or controlled by the federal government. The state housing board is given the power to approve or disapprove of members of a housing authority and to remove members after a hearing for cause shown. In addition the state housing board has certain powers of regulation and inquisition.

-1 New York, where the state housing board has been especially active, its powers with respect to housing authorities ${ }^{11}$ are even more limited than those of the Illinois board. This was probably due in part to a rather peculiar present political situation and in part to a feeling that slum clearance and low-cost housing is so peculiarly a local problem that it should be carried on by municipalities without state interference or control. Even in New York, however, the state housing board was given powers which will enable it to be extremely helpful in the development of the policies of housing authorities.

\section{Drafting the Act-Order of Material}

The form of a housing authority law is, of course, a matter of but secondary importance so long as it contains the essentials. Uniformity or at least similarity of arrangement, and, at least to an extent, of phrasing, are, however, helpful to people working with the laws of various states and simplify the interchange of ideas in case any changes are deemed desirable. Housing authority laws introduced recently in several legislatures contain a similar arrangement of material which is substantially as follows:

Title

Preliminary Recitals

Section 1. Short Title.

"N. Y. Laws I934, c. 4 . 
Section 2. Definitions.

Section 3. Declaration of Necessity and Public Policy.

Section 4. Creation of Authorities and Appointment and Removal of Commissioners.

Section 5. Interested Commissioners or Employees.

Section 6. Organization of Authorities.

Section 7. Compensation and Expenses.

Section 8. Powers of an Authority.

Section 9. Eminent Domain.

Section ro. Zoning and Building Laws.

Section II. Indebtedness.

Section I2. Arrangements with Federal Government.

Section 13. Powers and Duties of Housing Board.

Section I4. Filing Plans, Etc., with Housing Board.

Section 15. Security for Funds Deposited by Authorities.

Section 16. Advances by City to an Authority and Acquisition of Property from a City or Government.

Section 17. Tax Exemptions.

Section 18. Dissolution.

Section 19. Repeal of Inconsistent Provisions.

Section 20. Effect of Partial Invalidity.

Section 2r. Emergency Clause.

The above outline will serve probably as well as any other as an order of discussion.

\section{Drafting the Act-Specific Provisions}

The title of the act must comply with the requirements of the state in which it is enacted. In particular it is essential that the title contain sufficient description of all of the subject matter and, accordingly, it is suggested, especially in a state requiring a long form of title, that the title be drafted last. The inclusion and form or preliminary recitals depend upon local practice. The draftsman may find of assistance the form of recitals in the bill recently introduced in the West Virginia Legislature.

The use of a short title (Section I) is, of course, of assistance for easy reference. The important considerations in a short title are that it shall be descriptive but shall not be subject to confusion with titles of other acts.

A section on definitions (Section 2) seems highly desirable. The definitions should be carefully checked against other legislative or judicial definitions in the state in order to promote consistency of definitions so far as feasible. In Illinois the definitions appear after the body of the act but it would seem that in general it is advisable to define a term before rather than after using it.

A declaration of necessity and public policy (Section 3) should be supported at any legislative hearing by specific findings of fact. The following is a rather terse form of declaration:

Section 3. Declaration of Necessity and Public Purpose. It is hereby declared as a matter of legislative determination that in order to promote and protect the health, safety, morals and welfare of the public, it is necessary in the public interest to provide for the creation of public corporate bodies to be known as housing authorities, and to confer upon 
and vest in said housing authorities all powers necessary or appropriate in order that they may engage in low-cost housing and slum clearance projects; and that the powers herein conferred upon the housing authorities, including the power to acquire property, to remove unsanitary or substandard conditions, to construct and operate housing accommodations and to borrow, expend and repay moneys for the purposes herein set forth, are public objects essential to the public interest.

The question of the manner of creating authorities and the appointment and removal of members of an authority (Section 4) is one for extensive discussion and careful definition. The definition of an area, the determination of necessity for the creation of an authority and the appointment and removal of original and successor members of an authority are all matters peculiarly affected by local conditions. Two points should, it seems, be kept in mind in any event, first, the desirability of having the appointments for staggered terms so that continuity of management can be assured and, second, the necessity of avoiding the possibility of attack on the ground of improper delegation of legislative authority. The section should be carefully phrased so that the appointment of the members and probably the filing of a certificate as well shall be conditions precedent to the creation of an authority, but the authority should not be stated to be "created by" those having power of appointment.

The function of Section 5 dealing with interested commissioners or employees is obvious. Care should be taken in the drafting of this section not to make the restriction so severe that individuals whom the authority would desire to have as members or employees would be automatically disqualified.

If the section dealing with appointments does not designate which appointee shall be chairman, provision should be made in Section 6, dealing with organization of authorities, for the selection of a chairman. In order to avoid any possibility of requiring that action by all members of an authority shall be required, it should be stated definitely in the act that a majority shall constitute a quorum. In general it would seem desirable to provide (Section 7) that no member of an authority shall receive any compensation, but shall be entitled only to reimbursement for any necessary expenditures.

Section 8, defining the powers of an authority, should be very carefully drafted. Conditions have been changing so rapidly that no precedent offers a complete solution to the present drafting problem. Any attempt to limit the powers of a housing authority to precisely the form of activity in which it is at present contemplated that it will engage is practically certain to cause future embarrassment. Different housing authorities, and even the same authority in the case of different projects, may either (a) acquire the land from private owners, build and operate, or (b) acquire the land from the United States, build and operate, or (c) acquire a partially completed building from the United States, complete the project and operate it, or (d) acquire a completed building from the United States and operate it, or (e) lease a completed building from the United States and operate it, or ( $f$ ) act as agent for the United States in connection with any part or all of the activities of land assemblage, con- 
struction and operation. No uniform technique has been or probably will be developed, at least in the immediate future, and it is extremely important that the powers given to a housing authority be as broad as possible. The restriction upon the use of such powers will, of course, be imposed by the loan agreement. Care should be taken to avoid conflict with other public bodies or commissions.

The provisions relating to the exercise of the power of eminent domain should be carefully drafted with a view to obtaining as expeditious and inexpensive procedure as is permissible under the state constitution. In slum clearance, especially, the use of eminent domain to clear titles will probably be quite general.

Although it would seem generally preferable to include in Section to provisions subjecting an authority to the planning, zoning, sanitary and building laws, ordinances and regulations applicable to the locality in which the project is situated, such laws should be carefully studied so that if possible the authority may be exempted from the application of laws or regulations which would seriously interfere with its functioning.

Provisions relating to the indebtedness of an authority (Section Ir) should be as broad as possible. It would seem generally unnecessary to insert detailed provisions for the issuance of revenue bonds. This question and the contents of the entire section should be very carefully checked by competent bond counsel. It is desirable in any event to provide for the issuance of corporate obligations secured by a mortgage on the property of the authority.

Section 12, relating to agreements with the federal government, is probably unnecessary but would seem desirable in order to remove any possibility of criticism of the supervision and control imposed upon an authority under a loan agreement with the United States.

The question of the substance of the provisions to be included in Sections 13 and I4 defining the relation of an authority to the state housing board has been discussed above. The New York and Illinois laws offer interesting precedents.

In order that funds loaned to an authority by the United States and deposited by the borrower may be "reasonably" secured, it would seem desirable to insert a section authorizing state banks to give surety bonds and/or deposit collateral to secure the funds of the authority. The state laws should be carefully checked in order to determine whether this is possible and, if so, how it can be done.

In order that an authority may have funds which it needs for preliminary work and for general administration expenses, the city or other political unit in which it is operating should be authorized to make loans to it from time to time. The amount which the municipality should be authorized to lend for such purposes will, of course, vary greatly in different states, but without some funds it will be extremely difficult for the authority to work up any project. The municipality should also be authorized (Section 16) to transfer property to an authority in case it wishes to make a contribution to a project. 
The question of tax exemption (Section 17 ) raises an extremely controversial issue. The objections to tax exemption, both practical and theoretical, are obvious. On the other hand it would seem that the city should make some contribution to a local project. The compromise embodied in the New York Act which provides that the city may collect an amount not in excess of the sum last levied as an annual tax upon the property of the authority prior to the time of its acquisition by the authority seems a reasonable compromise. In any event, it would seem that the securities of an authority should be exempt from taxes.

Provisions for dissolution (Section 18 ) should require satisfactory provision for creditors and the payment of the balance either to the state or to the city as may be deemed advisable. The Illinois law contains an interesting statement of alternatives. Sections 19,20 and 2 I dealing respectively with repeal of inconsistent provisions, effect of partial invalidity, and an emergency clause, present local problems and should be carefully phrased to comply with local practices.

\section{Conclusion-A Caveat}

This article is being written only about seven months after the adoption of the first public housing authority law and about three months after the enactment of the second. In so new a field the suggestions and comments set forth herein must be considered tentative and subject to revision, excision, and addition as the housing authority legislation meets the test of actual operations. 